\title{
The effects of $ß$-alanine on body composition and performance measures in collegiate females
}

\author{
Amanda Buckley ${ }^{1}$, Abbie Smith², Chelsey Scoggins ${ }^{1}$, Craig Jones ${ }^{1}$, Josh Holt', Elizabeth Sillasen ${ }^{1}$, Brooke Cox \\ Stacie Urbina', Bill Campbell ${ }^{3}$, Cliffa Foster ${ }^{1}$, Lem W Taylor ${ }^{1}$, Colin D Wilborn ${ }^{1 *}$ \\ From International Society of Sports Nutrition: 9th Annual ISSN Conference and Expo \\ Clearwater, FL, USA. 22-23 June 2012
}

\section{Background}

ß-alanine has ergogenic potential based on its relationship with carnosine. Carnosine is rapidly degraded into B-alanine and histidine as soon as it enters the blood. So there is no advantage to using direct carnosine supplementation. Previous studies have demonstrated that taking $B$-alanine orally is effective at increasing intramuscular carnosine levels. The resistance training athlete may experience a higher training volume. This proposed benefit would increase work capacity and decrease time to fatigue. Therefore, the purpose of this study is to evaluate recreationally active collegiate females, following an 8 week strength training program while consuming either $\beta$-alanine (BA) or placebo (PL) for body composition and performance changes.

\section{Methods}

Sixteen collegiate females $(21.0 \pm 2.19 \mathrm{yrs}, 64.76 \pm 8.50 \mathrm{~kg}$, $164.98 \pm 6.97 \mathrm{~cm}, 30.11 \pm 5.08 \% \mathrm{BF})$ participated in a double blind placebo controlled strength training and supplementation study. Supplementation consisted of either $5 \mathrm{~g}$ maltodextrin or 3.4g BA (Dymatize Nutrition, Farmers Branch, TX), taken 15minutes prior to training. In addition, all subjects were given a post workout protein supplement of ISO-100 (Dymatize Nutrition, Farmers Branch, TX). All subjects were tested at baseline (T1), 4 weeks (T2), and 8 weeks (T3) over the 8 week supplementation study. Training consisted of $4 \mathrm{x}$ weekly upper and lower body resistance training. Body composition variables lean muscle mass (LBM), fat mass (FM), and percent body fat $(\mathrm{BF})$ were assessed using DEXA. Performance variables $\mathrm{VO}_{2 \max }$ (VO2), aerobic time to

\footnotetext{
* Correspondence: cwilborn@umhb.edu

'University of Mary Hardin-Baylor, Human Performance Lab, Belton, TX 76513, USA

Full list of author information is available at the end of the article
}

exhaustion (TTE), wingate peak power (PP), wingate mean power (MP), bench press 1RM (BPmax) and repetitions at 65\% (BPreps), leg press 1RM (LPmax) and repetitions (LPreps), vertical jump (VJ), and standing broad jump (BJ) were assessed using standard NSCA guidelines. Statistical analyses utilized separate two-way repeated measures ANOVA [time (T1 vs T2 vs T3) $\times$ group (PL vs BA)] for all dependent variables. 95\% confidence intervals were also run for each variable.

\section{Results}

There were no time $\times$ group interactions $(\mathrm{p}>0.05)$. Body composition (LBM, FM, BF) improved over time $(\mathrm{p}<0.01)$ for both groups. Maximal strength demonstrated a significant increase $(\mathrm{p}=0.001)$, and $\mathrm{VJ}$ increased at each time point $(\mathrm{p}=0.047)$. Confidence interval data demonstrated a significant increase in $\mathrm{VJ}$ and $\mathrm{BJ}$ for the BA group only from $\mathrm{T} 2$ to $\mathrm{T} 3$.

\section{Conclusions}

Results from this study suggest that $4 \mathrm{x}$ weekly moderate intensity training is effective for increasing body composition and strength. BA supplementation may provide some additional benefit under periods of long duration $(4+$ weeks) training on anaerobic power in women. These findings show $4 \mathrm{~d} /$ wk of moderate intensity training, in conjunction with BA supplementation, demonstrated no advantage on strength and body composition. However, as a potential result of increased training volume and power, a longer BA and training regiment may have a small advantage on sports performance including vertical and broad jumps, in collegeaged women.

\section{Acknowledgements}

This study was supported by Dymatize Nutrition 


\section{Author details}

1 University of Mary Hardin-Baylor, Human Performance Lab, Belton, TX

76513, USA. 'University of North Carolina Chapel Hill, Chapel Hill, NC 27599

USA. ${ }^{3}$ University of South Florida, Exercise \& Performance Nutrition Lab,

Tampa, FL 33544, USA

Published: 19 November 2012

doi:10.1186/1550-2783-9-S1-P2

Cite this article as: Buckley et al:: The effects of B-alanine on body

composition and performance measures in collegiate females. Journal of

the International Society of Sports Nutrition 2012 9(Suppl 1):P2.

Submit your next manuscript to BioMed Central and take full advantage of:

- Convenient online submission

- Thorough peer review

- No space constraints or color figure charges

- Immediate publication on acceptance

- Inclusion in PubMed, CAS, Scopus and Google Scholar

- Research which is freely available for redistribution

Submit your manuscript at www.biomedcentral.com/submit 